\title{
O REINO PORTUGUÊS "PARA A MAIOR GLÓRIA DE DEUS": PENSAMENTO POLÍTICO NAS CARTAS DE PADRE ANTÓNIO VIEIRA
}

THE PORTUGUESE KINGDOM “FOR THE GREATEST GLORY OF GOD”: POLITICAL THINKING IN THE LETTERS OF FATHER ANTÓNIO VIEIRA (I653I660) $)^{\mathrm{r}}$

\section{José Rubens de Souza Cardoso² Marcelo Tadeu Santos ${ }^{3}$}

RESUMO: A pesquisa proposta busca compreender as relações entre a Igreja Católica e a Monarquia durante o Antigo Regime português, partindo da análise de cartas escritas pelo religioso Padre Antônio Vieira (1608 - 1697) que foram destinadas aos reis de Portugal no século XVII. Isso posto, buscamos descobrir o que o monarca deveria fazer para conduzir melhor sua vida e a de seus súditos, assim nos interessou o que o jesuíta pensava do poder e do estado. $O$ itinerário utilizado consiste na intenção de buscar nas palavras de Vieira, o pensamento político no qual ele, profundamente influenciado com a ideia da firmação de um Estado católico e evangelizador, se posiciona diante de um período de relações de poder em constante movimento. Nessa trilha, utilizamos como referencial metodológico, as noções de análise do discurso de Eni Orlandi e do paradigma indiciário de Carlos Ginzburg.

Palavras-chave: Antônio Vieira. Antigo Regime. Monarquia portuguesa. Religiosidade católica. Poder.

\section{Considerações preliminares}

"Não há nada mais político do que dizer que religião e política não se misturam.”

- Desmond Tutu

\footnotetext{
I Artigo apresentado ao Centro Universitário de Brasília (UniCEUB) como pré-requisito para a obtenção de Certificado de Conclusão de Curso de História.

${ }^{2}$ Graduado em História pelo Centro Universitário de Brasília (UniCEUB). Licenciado em Pedagogia pelo Instituto de Educação Superior de Brasília (IESB). Pós-graduado em Educação, Política e Sociedade pela Faculdade de São Vicente. Atualmente é professor de Educação Básica da Secretaria de Educação do Distrito Federal (SEEDF).Email: rubenshistoriador7@gmail.com.

3 Mestre em História pela Universidade de Brasília -UNB e professor do curso de Direito do UniCEUB.
} 
O presente artigo aqui apresentado se destinou a compreender as relações políticas envolvidas entre a Igreja Católica (representada por Antônio Vieira) e a monarquia portuguesa durante o Antigo Regime português. Para isso, foi feita uma análise de cartas escritas pelo padre Antônio Vieira ${ }^{4}$ (1608 - I697). Essas epístolas foram destinadas aos reis de Portugal com o intuito de lhes advertir sobre as posturas que deveriam tomar frente a Deus e aos seus súditos para manter o ordenamento social no qual estavam inseridos.

Esta proposta de estudo das cartas de padre Antônio Vieira pretende entender a forma como Antônio Vieira se enxerga dentro do conjunto das relações sociais de seu tempo. Está centrado em ver a forma como um personagem da posição social de Vieira entende o mundo e suas relações de poder, a forma como concebe os mecanismos fundamentais para o estabelecimento de equilíbrios políticos que têm como horizonte o estabelecimento de pactos e de complexas teias que configuram um sistema pautado em redes clientelares ${ }^{5}$ de participação política, cujo horizonte é delineado pela ideia de conciliação.

O estudo foi referenciado com as orientações metodológicas da noção de historiador-detetive de Carlo Ginzburg e da contribuição sobre análise de discurso contida na produção de Eni P. Orlandi, pois, por se tratar de uma fonte epistolar com uma sofisticada linguagem teológica com o uso de alegorias complexas é necessário que o investigador se atente aos pormenores contidos no documento. Conforme Eni P. Orlandi (2003, p. 26) a análise do discurso "visa fazer compreender como os objetos simbólicos produzem sentidos, analisando assim os próprios gestos e interpretação que ela considera como atos no domínio simbólico, pois eles intervêm no real do sentido".

\footnotetext{
${ }^{4}$ Cartas publicadas na obra Cartas do Padre Antônio Vieira coordenadas por J. Lúcio Azevedo. Apesar da diversidade de cartas redigidas por Vieira, as utilizadas nesse artigo foram selecionadas de acordo com os objetivos da pesquisa.

${ }_{5}^{5}$ Redes clientelares consistem em um conceito utilizado na historiografia política ao tratar do Antigo Regime português, o termo atenta para uma relação política pautada em acordos do tipo patrão-cliente, onde as figuras políticas possuem um certo vínculo de dependência, e é comum agraciar os mais estimados.
} 
Se tratando de uma pesquisa que tenta explorar com precisão as informações indiretas deixadas por Vieira, é importante a compreensão de que "o conhecimento histórico é indireto, indiciário e conjectural” (GINZBURG, 1990, p.157). Pois aqui se procuram indícios e informações indiretas que remontam a uma projeção da realidade estudada.

O método indiciário, embasado no livro Mitos, Emblemas, Sinais: Morfologia e História de Carlo Ginzburg, se refere a um tipo de investigação que consiste em buscar nas fontes documentais, pistas, indícios, vestígios imperceptíveis para a maioria, que sirvam para captar uma realidade mais profunda acerca do que está sendo estudado. Nas palavras de Ginzburg:

O que caracteriza esse saber [de tipo venatório] é a capacidade de, a partir de dados aparentemente negligenciáveis, remontar a uma realidade complexa não experimentável diretamente. Pode-se acrescentar que esses dados são sempre dispostos pelo observador de modo tal a dar lugar a uma narrativa (1992, p. 152).

Considerando as fontes como indícios que nos permitem a construção de representações acerca do passado, o historiador constrói uma narrativa, na qual o objetivo é a diversificação do conhecimento histórico, sem espaços para verdades absolutas. A partir disso, e de acordo com os objetivos propostos, nos colocamos como capazes de resignificar os padrões analíticos sobre o final da Idade Média, destacando que o poder religioso, assim como o político, não se encontra centralizados em um único polo, como recorrentemente se interpreta, mas circula por todos os âmbitos da sociedade.

A questão inicial que norteia o presente trabalho é refletir sobre de quais maneiras a religiosidade Católica, representada aqui por Vieira, buscava determinar as posturas políticas e morais de seus nobres ouvintes.

As cartas escritas por Antônio Vieira, por sua vez, nos possibilitam outra problematização que tem um enfoque mais voltado para o que a historiografia conhece como Nova História Política que por acreditar que "a realidade social é 
muito mais rica, mais variada, complexa do que a imagem simplificada que propõem todos os sistemas de explicação" se destina a estudar os diversos "campos políticos" na sociedade partindo da perspectiva de que o poder não está concentrado apenas em uma única parte elitizada, mas que está em toda a sociedade.

Dessa forma, a Nova História Política se apresenta como uma importante ferramenta para a compreensão das relações políticas. $O$ historiador francês Rene Remond que escreveu sobre a renovação da história política orienta que:

Descartemos a solução fácil que seria definir o político pela enumeração das questões que fariam parte de seu domínio, ou pela delimitação de um espaço que lhe seria próprio. Com exceção de um núcleo restrito que lhe é inseparável, o político é como esses Estados dos quais a geografia não delineou previamente os contornos e a história não parou de modificar os limites: o político não tem fronteiras naturais. (REMOND, 2003, p. 442).

Diante desse estudo minucioso e complexo de como é dado o poder, esse presente artigo também se norteia na problematização da ideia comumente assimilada de um estado monárquico totalizante. Pois, apesar do poder do monarca ser comumente considerado absoluto, ele era na prática, compartilhado por outros corpos da sociedade como as elites locais e o clero, sendo essa uma característica incorporada na noção de cultura política trabalhada por Serge Berstein, pois como aponta o autor, compreender a cultura política de um grupo social ajuda a entender melhor os comportamentos do mesmo.

É especialmente à classe clerical que o estudo aqui apresentado é destinado a observar - por meio da figura de Antônio Vieira que faz do artefato epistolar um espaço de disseminação de suas ideais políticas ou ideário que ele possui para o que o mesmo acredita ser o mais prudente dentro de seu posicionamento como representante pastoral do catolicismo apostólico romano.

\footnotetext{
${ }^{6}$ REMOND, René in LINHARES, Maria Y. Leite. Por quê a História Política?. 1993, p. 8
} 
O trabalho com as cartas está dentro de uma linha de pesquisa que reflete que o estudo do poder pode ser realizado de diferentes perspectivas, principalmente, com teor minucioso sobre a forma como o poder é exercido até nas pequenas instâncias7.

Vendo a história como o conhecimento do passado através de um testemunho documental, o conteúdo epistolar de Vieira se torna um testemunho de como era coordenado o poder entre ele e o monarca, visto que, aquele momento histórico possui uma conduta política enraizada no período medieval, onde o rei era a figura central de uma rede de mecanismos que davam sustentação e legitimidade ao exercício do poder no chamado Antigo Regime português.

\section{O estudo do poder para o contexto do padre Antônio Vieira}

O envolvimento entre história e política sempre foi um assunto versado entre as escolas historiográficas, entretanto, durante muito tempo esse envolvimento pareceu de certa forma tão simples que muitos historiadores não se atentaram ou até hoje não se atentam para as diversas e complexas formas de detectar e analisar a presença do poder na história.

Em especial no Brasil como em outros países ocidentais é significante o trabalho com história política por parte de muitos autores, mas um aspecto evidente é que as perspectivas utilizadas para refletir sobre a história política foram encabeçadas pelas correntes epistemológicas que influenciaram os historiadores, tais como o marxismo, o positivismo, o estruturalismo e entre outras histórias. Saber desse feito é importante para relacionar que o estudo do poder fora muito vinculado com a forma que o pesquisador pensava a história e em qual teoria mesmo se orientou em suas produções. Visto que é fundamental para a produção de uma pesquisa em história política, que o autor tenha um conceito do que venha a ser o poder.

\footnotetext{
7 Pequenas instâncias se referem a ambientes de pequena expressão comparados ao poder central do soberano, mas onde existam relações de poder envolvidas.
} 
Conforme é apresentado por Francisco Falcon, no capítulo História e poder do livro Domínios da História, entre a historiografia brasileira dos anos 50 a 70, imperou o que se pode chamar de história política tradicional. A preocupação da história esteve muito em torno do estudo de fatos históricos de grande abrangência e se fazia uma análise debruçada nas figuras que ocupavam espaços de poder mais evidentes, sendo uma análise um tanto simples em relação ao que se produz atualmente no estudo dos personagens políticos.

\begin{abstract}
Houve entanto que superar os obstáculos epistemológicos até então expressos de maneira antagônica: "tudo é política" versus "a política não existe". A primeira preposição, típica da tradição oitocentista, é idealista e conduz, no máximo, ao "jurisdicismo" formalista e narrativo; a segunda deriva de uma certa visão marxista das coisas (equivocada, é bom frisar) em cujo nome se opera a redução dos fenômenos de consciência e de vontade a simples reflexos de forças econômicas e sociais. A política, neste caso, não passaria de um problema econômico mal colocado. (FALCON, 1997, p. 122).
\end{abstract}

Dentro daquela perspectiva tradicional de se pensar o político, nota-se que o poder é mais reconhecido nas situações de conflito, porque no conflito as articulações para alcançar ou manter um respectivo espaço de poder eram mais evidentes por conta das alterações e do impacto que tais fatos históricos refletiam na sociedade estudada. Diante do fato de que no Brasil, os caminhos para renovação da história política estão em grande discussão, nossa pesquisa se enquadra numa tentativa de estudar o poder dentro de um universo de particularidades que exigem esse olhar histórico com contribuições das ciências sociais.

A fundamentação teórica de nossa pesquisa está concentrada na constituição de uma discussão que apresenta o perfil da participação política da religiosidade dentro da sociedade medieval que emerge das cartas escritas por Padre Antônio Vieira (I608 - 1697) como parte de um universo onde cada corpo social tem sua função, se tratando de um contexto histórico-político entrelaçado de relações de poder em constante movimento, relações coordenadas por uma hierarquização e complementação dos espaços políticos. 
Considerando que as cartas expressam uma conduta política que possui características em comum com a Idade Média, foi utilizado o conceito de longa Idade média do medievalista francês Jacques Le Goff que em sua renomada obra Uma Longa Idade Média, afirma que, culturalmente, o período medieval possui um conjunto de valores e uma ideia de homem que vai mais além do recorte comumente utilizado para sinalizar o fim desse período. Conforme se percebe no decorrer desta pesquisa a ideia de poder por parte de Vieira, é inspirada na concepção teológica medieval.

É partindo dessa posição sobre a cultura política e religiosa do Antigo Regime português, que a presente pesquisa aborda o cenário no qual as fontes estão inseridas. Como lembra a historiadora Maria Filomena Coelho:

Sem dúvida, poder-se-ia argumentar que nossos mais ilustres historiadores, quando levados a se interrogar sobre determinadas especificidades brasileiras, encontram a resposta na Idade Média portuguesa. (COELHO 2002, p. I130).

Uma dessas especifidades encontradas no Brasil Colonial é presente na cultura política, muito do comportamento político do século XVII tem raízes no medievo português, o que ajudar a compreender com um olhar medieval sobre o Brasil através do conceito da longa duração, valores como honra, hierarquia e fidelidade são sentimentos que continuam com a mesma conotação que se tinha na Idade Média.

Nessa mesma perspectiva é importante destacar aqui os estudos do historiador Jêrome Baschet sobre a herança medieval existente nas relações entre Igreja Católica e a monarquia durante o Brasil colonial, pois para ele as funções esperadas do rei não mudaram, em absoluto, e resumem-se ainda - referindo-se à Idade Moderna - pelos termos de justiça e paz, além disso, o mesmo defende que a "igreja medieval" e a "igreja colonial" são extremamente semelhantes em diversas características como estruturação interna do clero, papel das ordens mendicantes e entre outras similitudes. 
Uma das propostas desta presente investigação sobre Antônio Vieira é relacionar o papel do monarca com a manutenção da ordem, da paz e da justiça. Partindo desse pensamento é importante frisar que o contexto histórico no qual ele está inserido se trata de um todo harmonizado, mas nem por isso livre de conflitos em tornos de interesses distintos. Existe uma concorrência entre os discrepantes segmentos que precisa ser administrada por um poder central que se coloca como fonte mantenedora da paz e justiça, onde ambas as virtudes são entendidas nesse contexto como conceitos voltados para preservação dos privilégios originados num ordenamento originário do mundo.

Como aponta o historiador e jurista António Manuel Hespanha, a função do soberano era então de garantir em seu reino a manutenção do exercício dos direitos e deveres, dando a cada corpo social o que ele merecer, dentro de seu papel na sociedade. O discurso contido nas cartas entende que o poder e a hierarquia são indispensáveis para se estabelecer a conciliação entre os homens.

No meio de sua disputa com os colonos, no período em que serviu como missionário na região do Grão-Pará e Maranhão, pela regulação e limitação da escravização do indígena, padre Vieira não deixava de demonstrar que o poder do monarca não é um poder totalizador, mas um poder regulado pelas limitações do pacto entre os diversos estamentos sociais. Assim sendo, este rei não se configura como um tirano usurpador. Como nos aponta Hespanha, “(...) o único limite efectivo dos poderes era, então, o dos direitos dos vassalos decorrentes de contrato estabelecido entre particulares ou com o soberano ou de privilégio por este concedido, pois se entendia que o rei não podia modificar essas situações a não ser por utilidade pública manifesta ou com fundamento em erro seu mas provocado pela outra parte." (1982, p. 310).

Como afirma a historiadora Maria Filomena Coelho, as relações da monarquia com os privilegiados são uma estrada de duas mãos. A mera existência da aristocracia contribui diretamente ao engrandecimento do rei, que deve se rodear de grandes senhores. 
Quanto mais nobres tenha um príncipe ao seu serviço, mais poderosa será sua imagem de soberano e sua glória aumentará na mesma proporção do incremento do poder de seus senhores. (COELHO, 2002, p. I19). Partindo desta perspectiva, os demais poderes se encontravam numa condição de concorrência com o poder central.

Aquele que recebe a doação do monarca deve valorizá-la, cumprir com o papel que se espera dele, pois o recebe-la consiste em ser amado pelo seu rei pelos serviços que lhe prestou, mas dentro da lógica do império e da Cristandade. O sujeito agraciado colocava-se numa posição de destaque e diante dele se desfraldava a possibilidade de um futuro glorioso, onde a sua movimentação dentro do império estaria articulada pelos laços que ele era capaz de produzir por meio da sua capacidade de prestar os serviços esperados.

Tal panorama revela também a disposição das elites locais e até mesmo centrais para estabelecer estratégias políticas que exploravam o mecanismo das mercês a fim de garantir os seus nichos de poder. Desmerecer tal dádiva, mesmo para um membro da alta nobreza, era abrir mão de uma posição de destaque dentro do império, de ir contra a lógica da estruturação das relações políticas que priorizava a constituição de redes de favores mútuos como pontos nodais para a sobrevivência do império.

Os poderes concorrentes do rei desenhavam suas estratégias de poder dentro desse quadro de encadeamentos, cuja arquitetura política fundava-se na capacidade de manter viva uma autonomia jurisdiciona relativa frente à coroa, podendo exercer o poder político de acordo com seus interesses, mas dentro da lógica pactista.

Nessa perspectiva, o rei aparece indiretamente sujeito aos constrangimentos e contingências impostos pela economia de favores, e podia ser clara e eficazmente pressionado por determinadas casas poderosas no sentido de tomar esta ou aquela resolução, como na prática, sucedia com os outros atores políticos. O seu poder, apesar de ser considerado absoluto, era, na prática, muito mais restrito do que podia o discurso político deixar entender. (XAVIER; HESPANHA, 1998, p. 347).

Por fim, podemos entender que, na percepção de Antônio Vieira, o monarca tem a graça e a concessão de mercês como principais instrumentos para o 
estabelecimento da paz e da justiça. Enquanto a graça reforça os mecanismos que incentivam a fidelidade dos envolvidos, deixa também sempre aberto no horizonte do transgressor a possibilidade de redenção. A mercê constitui-se num pilar de reforço dos laços políticos e sociais. É por intermédio dela que se constituirá uma complexa rede de auxílio mútuo, fundado na prestação e reconhecimento de serviços, cujas dinâmicas vão desenhar os principais traços da cultura política do Antigo Regime português.

Isso possibilita compreender que o soberano não dispõe de uma capacidade de ação política ilimitada, fazendo e desfazendo de acordo com os seus interesses, mas se vê obrigado a compartilhar o cenário com outros poderes, ofertando mercês e benefícios àqueles que lhe servem, e distribuindo a sua graça para se legitimar como o líder capaz de conduzir o Império Cristão à redenção. Nessas condições, tentamos compreender melhor quais as posturas políticas e morais que a realeza deveria tomar para melhor governar seus súditos e alcançar a vida eterna, pois para a filosofia teológica da época, os executivos do poder deveriam caminhar de mãos dadas com a salvação do espírito das pessoas.

As cartas que foram analisadas neste trabalho foram escolhidas pelo fato de serem documentos que apresentam através da escrita, uma representação da relação entre o representante da Companhia de Jesus, Padre Antônio Vieira e os reis de Portugal, Dom João IV e Dom Afonso VI.

No acervo de cartas analisadas, seis delas são epistolas enviadas do Padre Antônio Viera para o rei Dom João IV, a última é uma carta do mesmo para o então rei ${ }^{8}$ Dom Afonso VI escrita no Maranhão. O envio das cartas foi realizado num período em que Vieira teria exercido a função de chefe da missão do Estado do GrãoPará e Maranhão, nos anos de 1653-1660, essa posição social lhe garantia uma função de destaque no projeto colonizador português, portanto o período estudado foi

${ }^{3}$ Herdeiro de D. João IV, que assumiu o trono português após o pai, fazendo com que padre Vieira perdesse a dimensão da influência que possuía antes. 
escolhido no sentido de observar como o pregador lida com essa importante influência para a corte portuguesa.

Em relação ao conteúdo do documento, Vieira relata ao rei de Portugal, os acontecimentos referentes à missão e apresenta suas considerações sobre o progresso e os empecilhos que atrapalham o desenvolvimento do serviço missionário na região. Ao fazer esse trabalho descritivo, ele relata a participação de indivíduos ou grupos envolvidos naquele determinado contexto e processo. Eis uma condição que exige uma atenção especial por parte de nossa investigação, relatar como os personagens se comportam e dizer como esses personagens devem se comportar, faz do relatório missionário uma espécie de testemunho do pensamento político do pregador, onde o mesmo dita o que ele acredita como ideal de sociedade.

Além disso, essa descrição trata de uma prestação de serviço do padre em relação ao monarca, onde podemos analisar a função do religioso como conselheiro real e do monarca com a responsabilidade da manutenção da ordem, onde seu papel como a cabeça do reino exige uma função de guardião da paz e justiça na colônia de Portugal, sendo essa característica uma herança medieval como aponta o historiador medievalista francês Jérome Baschet anteriormente mencionado.

A análise documental mostrou que há incidência de uma pluralidade de interesses envolvidos no cenário político-cultural de uma época que via no caminho da salvação o sentido das coisas, resultou na ideia de que os representantes cristãos possuíam o papel divino de estar na terra para orientar os homens na sua conduta cotidiana. Por intermédio dos conselhos cristãos contidos nas epistolas estudadas, que Padre Antônio Vieira encarregava-se a incumbência de ser o braço eclesiástico a serviço da monarquia de sua pátria e da manifestação da fé católica.

O discurso proferido pela figura religiosa em questão, revela que aqueles que possuíam a autoridade de reger o comando sobre a administração temporal e espiritual da vida das pessoas - Monarquia e Religiosidade - legitimavam sua autoridade na ideia de que seus conselhos eram oriundos da graça divina, e, portanto, 
deveriam ser obedecidos para que dessa forma fosse mantida a ordem necessária para o bom funcionamento do universo político-social no qual se inseriam.

Qualquer outra solução era entendida como pecado, pois se acreditava que, além de ameaçar as tradições sociais e políticas que dão sentido às suas vivências, conduziria à mentira, e iria contrariar o sentido histórico que os levariam á redenção divina, o que poderia implicar na propagação da desordem, da injustiça e condenação das almas.

\section{O pensamento político de Vieira por uma Razão de Estado católica}

Essa investigação proposta também tenta perceber como Antônio vê o mundo no qual está inserido e como o mesmo busca soluções para os problemas enfrentados, nessa trajetória, buscamos compreender o pensamento político que Vieira orquestra em seus conselhos, para os administradores do reino português. Nas suas atribuições sacerdotais, é fácil perceber e assimilar suas posturas voltadas para o bem-estar das almas, para o desenvolvimento das virtudes cristãs e demais necessidades de âmbito espiritual, portanto para compreender o sentido de seus argumentos, no que se refere ao âmbito político, é preciso ter noção de "quais águas Vieira bebeu", e quais as possíveis bandeiras levantadas pelo missionário jesuíta.

A noção de política contida na consciência de padre Vieira, permite salientar a razão de estado para ele, sendo a razão de estado entendida nesse trabalho conforme o conceito usado pelo filósofo, Eugênio Gonçalves:

O Estado, visto como um ser autônomo, guiado por seus próprios interesses, compartilha em sua razão de ser, a razão de Estado, a importância fundamental de todos os seres vivos: a da sobrevivência. Como qualquer ser, também deve ele sobreviver a qualquer custo. Segundo Meinecke, a luta por segurança e autopreservação a qualquer preço está por trás de todas as ações guiadas pela razão de Estado; condená-la é tão razoável quanto condenar um leopardo por seus atos. (GONÇALVES, 2010, p. Io).

A razão de estado em Vieira, implica no que o mesmo acredita ser o conveniente para justificar os esforços feitos pela monarquia portuguesa, para a 
manutenção do poder, esforços esses que podem ser executados pela força quando necessário, assim como orienta a concepção tradicional de Razão de Estado para Nicolau Maquiavel9. Os princípios dessa razão de estado podem ser mais explícitos nos sermões proferidos por ele, mas a característica privada do epistolário, e os assuntos práticos tratados nele, exigem uma atenção maior para os recursos retóricos usados por Vieira para resignificar o sentido de estado que ele professa.

Dentro dessa lógica é pertinente ter consciência da justificação e de como surge o raciocínio político que permite ao religioso inaciano, ditar o que lhe convém ser certo ou errado para administração do reino e do comportamento das pessoas. Utilizando de seu espaço de influência, seja o púlpito, seja a escrita de sermões, sejam as cartas destinadas a pessoas importantes na extensão do império, padre Antônio se mostrava bem articulado nas causas políticas, mesmo se o tema debatido fosse religioso.

Portanto esse raciocínio político que orientava as posições dele, fazia com que o mesmo, na qualidade de pastor, fosse obrigado a fazer até mesmo politicamente as devidas mediações entre os homens e vontade da providência, elogiando as prudentes medidas tomadas por eles, corrigindo os possíveis deslizes e erros que com a misericórdia e redenção podiam ser perdoados. Esse método podia ser claro e evidente para governo das almas, mas também devia ser seguido para a boa governança encabeçada por valores cristãos, tanto é que os cargos políticos que Vieira sugeria, sempre eram recomendados a valorosos homens católicos. Como nas próprias palavras de Vieira, se pode notar a ideia de estado presente nas cartas:

Os outros reinos da cristandade, Senhor têm por fim a conservação dos vassalos, em ordem à felicidade temporal nesta vida, e à felicidade eterna na outra: o reino de Portugal, de mais deste fim universal a todos, tem por fim particular e próprio a propagação e a extensão da fé católica nas terras dos gentios, para que Deus o levantou e instituiu; e quanto Portugal mais se ajustar com este fim,

\footnotetext{
9 Esboço do conceito de Razão de Estado discutido em Gonçalves, Eugênio Mattioli. "Princípios da Razão de Estado em O Príncipe, de Nicolau Maquiavel." Filogenese. Marília 3.I (2010): 7-I4.
} 
tanto mais certa e segura terá sua conservação; e quanto mais se desviar dele, tanto mais duvidosa e arriscada.(VIEIRA, 1925, p 470).

A fé regulamenta a política, visto que o sentido da salvação não estaria apenas vinculado a um sentido de contemplação, pois a ordem seguida na vida terrena iria ser a mesma que traria felicidade na vida eterna. Essa inspiração que incentivava o pensamento político do padre jesuíta, se representa na tese de ver Deus como origem e fonte mantenedora de todas as coisas, concepção esta difundida pela patrística (tendo Santo Agostinho como principal expoente) e a escolástica (encabeçada por São Tomás) que permeava o conhecimento na igreja durante os períodos medievais.

\title{
Conforme resume Alves:
}

\begin{abstract}
A doutrina política de Tomás de Aquino está amparada nessa lógica da conciliação entre a filosofia aristotélica e a fé cristã e prevê a existência de uma Razão de Estado que acabaria impregnando o projeto messiânico do Quinto Império, sustentado por António Vieira. Sob a influência de Aristóteles, Tomás de Aquino percebia a communitas civitantes ou respublica, como realidade natural. Para o dominicano, o conjunto das relações dadas no âmbito da república, do Estado, eram uma realidade tão natural quanto aquela da organização familiar ou qualquer outra forma de congraçamento e convivência humana. O devir humano, entretanto, enquanto uma busca pelo aperfeiçoamento da própria natureza do homem, só poderia ser alcançado em Deus. Portanto, o objetivo ultimo das ações humanas excederia ao próprio homem, pois sua vontade, mesmo que de maneira inconsciente, o leva ao ser supremo. (ALVES, 2015, p 6r).
\end{abstract}

Em sua formação intelectual, Antônio Vieira teve acesso a obras católicas que contemplavam sobre o saber político, especialmente as obras de São Tomás de Aquino que eram presentes nas formações teológicas da igreja, durante e após a Idade Média. Essas leituras influenciaram o posicionamento no discurso político do inaciano que justificava seus argumentos embasados em passagens do evangelho e citações bíblicas conforme contatamos também nas fontes epistolares, mostrando que além do conhecimento teológico, o inaciano possuía certo conhecimento no que se refere a filosofia política, pois ensinamentos da Igreja mesmo voltados para o campo espiritual, eram ligados ao campo temporal. 
Em sua dissertação de mestrado, Deivide Rodrigues Alves levanta uma discussão aprofundada sobre a formação pregacional e as bases fundamentais do pensamento vieirense, sobre a influência de Aquino sobre o pensamento político de Vieira ele conclui que:

Portanto, o que vemos na filosofia tomasiana é uma proposta de cooperação entre dois poderes com vistas à realização do fim último: redenção e salvação. À Igreja e ao Estado Tomás de Aquino fornece justificativas para as suas ações e defende o fortalecimento de ambos enquanto instituições independentes e complementares: a Igreja deve trabalhar para a sustentação ideológica dos poderes do Estado e o Estado, quando solicitado, deve exercer o seu poder protetor e repressivo em proveito da Igreja. (ALVES, 2015, p.63).

O estado existe para o bem comum desde que ele seguisse os conselhos da Igreja, tanto para os fins temporais e espirituais, Vieira percebe que o fortalecimento de ambas as instituições, consagraria ao melhor possível perante a vontade divina, o braço eclesiástico e braço secular devem andar de mãos para o maior proveito do reino de Deus, tanto no céu, como na terra e nas ações administrativas.

$\mathrm{Na}$ prática, essa aliança entre essas duas instituições formavam um engenhoso instrumento de controle, sobre a ligação entre Estado e Igreja, Alves afirma:

$\mathrm{Na}$ opinião de Vieira segurança do Estado é um direito inalienável e, para a sua consecução os governos deveriam, mesmo, confrontar as normas políticas, jurídicas, morais ou econômicas. A Razão de Estado tem por justificativa a necessidade de prover essa segurança inclusive para os governantes. Por outro lado, o Estado natural deve estender as suas ramificações para o sobrenatural, mediante a união com a Igreja, como havia propugnado Tomás de Aquino nas suas teses sobre as duas intuições. (ALVES, 2015, p. 65).

Essa união tão levantada por Vieira em suas cartas e sermões, para integrar o serviço do estado português com o serviço religioso, era também desejada para todos os participantes da estruturação social que ele estava inserido, em especial na missão do Grão-Pará e Maranhão, onde integrar o indígena fazia parte dos planos de Vieira para fortalecer o projeto de razão de estado que ele tinha em mente. Dentro dessa 
perspectiva orientada pelo evangelho, a Igreja recebia privilégios ao enaltecer os laços monárquicos.

Todas essas atribuições dadas ao monarca por parte de Antônio Vieira são ancoradas em um projeto político, projeto esse onde "os fins justificam os meios", onde se percebe que para essa ideia, ser cristão valoroso e ser obediente a coroa portuguesa faz com que o súdito mereça o reconhecimento dentro daquele universo. Os meios são inspirados em um fim que seja a redenção humana, dentro das epístolas é possível ver a conotação profética que o padre se refere a nação portuguesa, Portugal tem um papel importante na evangelização do novo mundo, e para o jesuíta, os fins das práticas do estado, devem ser resultados de uma harmonia entre todo os corpos sociais:

Deus é, portanto, a causa final do tempo e da história; e a felicidade plena só seria possível dentro de um plano salvífico que conduzisse a Ele. A porta para a salvação é oferecida por um profetismo essencialmente religioso, mas de cunho político-nacionalista. $\mathrm{O}$ Quinto Império, conforme as formulações de Vieira revelam é um projeto com finalidade religiosa e sobrenatural, metafísica; porém, a sua realização passa, necessariamente, por um plano político e temporal que garanta os meios práticos e materiais necessários à sua consecução. (ALVES, 2015, p.70).

Segundo essas considerações, notamos que a razão de estado para Vieira faz parte de um grande acordo entre a cidade terrestre (reino português) e cidade de Deus ${ }^{\mathrm{IO}}$ (reino dos céus), só a comunhão entre ambos grupos, pode resultar num estado português forte e vigoroso. O rei como representante de Deus para executar o poder deve ter consciência desse seu compromisso, e, portanto, deve seguir à risca os ensinamentos da Igreja, não apenas o rei, mas o súdito por mais simples e aparentemente fraco possa parecer, pode contribuir para esse projeto político almejado pelo inaciano, desde que ele cumpra os mandamentos e os conselhos católicos em seu cotidiano.

Em termos do governo das gentes, a Razão de Estado expressa no pensamento de Antonio Vieira dispõe providencialmente dos mais adequados meios, limitados e finitos por certo, mas aplicados de

\footnotetext{
${ }^{10}$ Cidade de Deus é um conceito utilizado por Santo Agostinho que se referia ao reino celeste governado por Jesus Cristo.
} 
forma a incorporar o reto fim que conduz a Deus. Desta maneira, em vez de atitudes, princípios ou intenções, a Razão de Estado, em Vieira, atende às práticas circunstanciadas da ocasião e das pessoas, os hábitos que reduzem os meios e um projeto teleológico que a todos condiciona. ( MANDUCO COELHO, 2003, p. 13I).

Essa justificativa de fazer a vontade da providência, faz com que o Estado seja "um conciliador de interesses", pois mesmo tendo o rei como principal figura na arquitetura política, o poder era partilhado entre diferentes setores muitas vezes tinhas divergências entre si. Mesmo os índios, se convertidos, poderiam participar desse universo sacralizado que Deus teria preparação para o império português.

O Estado forte de Antonio Vieira é o lugar privilegiado de atuação das vontades divina e humana. Aqui, Estado é mais que conciliador de interesses, sendo ele mesmo quem compõe e reconhece os interesses mais apropriados. Referem-se, esses interesses, os relativos à conservação e perpetuação da monarquia temporal. (MANDUCO COELHO, 2003, p. 130).

Assim como nos sermões analisados na obra de Alexandre Manduco Coelho, as cartas também reproduzem a noção de poder compartilhado, que é outra especificidade estudada neste trabalho, Vieira acreditava em um mundo onde os homens poderiam viver em união e fraternidade, o que estava evidente em suas determinações políticas, mesmo na solução de conflitos de partes divergentes. Essa característica se resume na seguinte afirmação:

A supremacia do Estado é certa. Não é o rei figura desprovidencializada que absolutamente determina os caminhos para seu 'corpo político'. Na verdade, o Estado entendido como espaço e elemento de revelação da união sacramental entre Providência e ação humana é quem se apresenta como chave do modo de pensar em Vieira. (MANDUCO COELHO, 2003, p. 132).

Esse estudo sobre a razão de Estado em Antonio Vieira ajuda a entender a orientação que move suas ações, onde para ele, o estado pode ser visto como um agente da vontade divina na terra, concepção esta, comumente exposta na era medieval, mas que permanece no pensamento político de Vieira, mesmo num contexto histórico onde, se tem grandes influências do humanismo. 
O estado no caso de Portugal existe com a razão de estabelecer o império mais importante entre os reinos dos homens, pois este é o desejo do reino dos céus. O conteúdo epistolar evidencia a imagem do monarca com este compromisso de guiar este estado forte para vencer as crises e desviar seus súditos do pecado.

\section{A autoridade do monarca e as atividades missionárias no Brasil Colonial}

Conforme exigência da fonte epistolar, antes de analisar seu conteúdo é importante ter consciência das questões políticas que envolviam os personagens inseridos e citados nas referidas cartas. $\mathrm{O}$ ambiente onde elas são escritas se refere, a um período de desenvolvimento do processo colonizador português na região norte da colônia. Diversas disputas eram entre jesuítas e colonos que conforme seus interesses no trato com os indígenas, concorriam para que suas exigências e orientações fossem acatadas dentro da política do império português.

Logo nas primeiras cartas de Antônio Vieira a serem estudadas por este trabalho, percebe-se nas palavras dele uma preocupação que ele tinha para com os índios e com a situação do estado português, pois o padre inicia o diálogo comentando sobre o atual quadro político daquela região, e em seguida faz conselhos em relação à escolha dos novos representantes do monarca português na região norte do país.

São lastimosas as misérias que passa esta pobre gente das Ilhas, porque como não têm com que agradecer, se algum índio se reparte não lhe chega a eles, senão aos poderosos; e é este um desamparo a que Vossa Majestade por piedade devera mandar acudir, com efeito: mas também a isto se acode nos capítulos de um papel que com esta vai. (VIEIRA, 1925, p. 417).

Conforme presente na citação acima, o autor faz um apelo ao monarca português, e ao levantar essa denúncia, ele menciona a palavra piedade, fazendo desse valor cristão um artefato para lembrar o líder político do seu compromisso com a fé religiosa e o bem-estar da sociedade. 
Referente à carta escrita em 4 de abril de 1654 , observa-se que na introdução desta correspondência, Vieira afirma que "nunca soube razões políticas", mas que por obedecer a realeza, iria fazer o relatório dizendo o que lhe parece estar acontecendo, esse posicionamento do pregador em proferir que não sabe de razão políticas é uma maneira que o mesmo encontra dentro das palavras para afirmar que todas as suas ações são baseadas na obediência. Com essas palavras, ele está retirando de si a figura de representação política e estaria enaltecendo a voz de conselheiro cristão, mesmo que conforme percebemos na discussão sobre razão de estado, Vieira possui sim razões políticas ao determinar o que lhe convém.

O trecho abaixo se refere a uma descrição de um ato do Padre Vieira que enaltece a participação dos índios na questão estudada, pois fazia parte do discurso dos jesuítas da região norte do Brasil, civilizar os índios para que além da promoção da fé cristã, essas pessoas se tornassem súditos para assim passarem a serem vistos como súditos da realeza portuguesa, sendo importantes no ideário de um reino português cristão e evangelizador, conforme era desejado por parte da coroa naquele momento.

Eu li aos índios, assim do Pará como deste Maranhão, a carta de Vossa Majestade traduzida na sua língua, e com ela ficaram mui consolados e animados, e se acabaram de desenganar que o não serem até agora remediadas suas opressões era por não chegarem aos ouvidos de ${ }^{\text {II } V . M ~ s e u s ~ c l a m o r e s ; ~ e s p e r a m ~ p e l o s ~ e f e i t o s ~ d e s t a s ~}$ promessas, tendo por certo que lhe não sucederá com elas o que até agora com as demais, pois as vêem firmadas pela real mão de V.M. (...) (VIEIRA, I925, p. 422).

O pregador Antônio Vieira faz um alerta sobre a injustiça presente no contexto político sua época, e para tal, ele usa o exemplo da escolha dos dois capitãesmores escolhidos para administrar o governo, além desse alarme sobre a exploração dos índios. Percebe-se que a utilização desses argumentos foram, estrategicamente escolhidos para fazer com que o monarca e receptor da carta, tenha o sentimento de compaixão e comoção perante tais acontecimentos relatados.

\footnotetext{
${ }^{11}$ V.M se trata da abreviação usada na época que se trata de Vossa Majestade.
} 
O fato do mesmo dizer ter escrito que teria lido a carta do monarca aos índios nos remete a perceber como esses personagens eram simpatizados por Vieira, e que o mesmo influenciando na ideia de irmandade dentro do cristianismo acreditava ser conveniente defender a paz e a unidade entre as classes sociais. No decorrer dessa carta analisada, o bem articulado Vieira vai relatando diversas situações que necessitam do posicionamento do monarca para obtenção da justiça.

Ele relata sobre a opressão dos colonos sobre os índios do Grão-Pará e Maranhão, onde os colonos disputavam com os religiosos o poder de fazer contato com os índios da região. Vieira reclama ao monarca sobre o descumprimento do dever por parte dos colonos, "O Maranhão e o Pará é uma Rochela de Portugal, é uma conquista por conquistar, e uma terra onde Vossa Majestade é nomeado, mas não obedecido.” (VIEIRA, I925, p. 422).

Fiz por três vezes requerimento ao dito Gaspar Cardoso se não intrometesse no que lhe não tocava, e era próprio de nossa profissão, e para que V.M nos mandára; mostrei-lhe e li-lhe, diante dos padres e de oito ou dez soldados que levava consigo, a ordem de V.M e a do Capitão-mor, e respondeu publicamente que a de V.M não podia guardar, e que a do capitão-mor não queria. Bem entenderam todos que este modo de falar era de quem se fiava em ordem secreta que tinha encontrada, e assim me declarou o mesmo Gaspar Cardoso por muitas vezes, e a diferentes pessoas, como consta por certidões juradas, nas quais, e em outras que envio, poderá Vossa Majestade mandar ver outras muitas circunstâncias deste caso mui notáveis e indignas. (VIEIRA, 1925, p. 428).

Para ajudar a entender o contexto citado no trecho acima, é relevante mencionar que de acordo com o conteúdo desta mesma correspondência, o nome citado de Gaspar Cardoso, se trata de um ferreiro escolhido pelo então capitão-mor do estado Inácio do Rêgo, para ser cabo de uma missão onde o mesmo poderia ir a um determinado lugar para buscar gentios (índios) para trazê-los.

Essa situação demonstra um tipo de disputa de poder recorrente, tal condição afrontava uma conquista dos religiosos da Companhia de Jesus, que seria uma regulamentação citada por Vieira anteriormente.

Assim mais manda V.M no regimento dos capitães-mores que, sob pena de caso maior, nenhuma pessoa secular, de qualquer estado ou 
condição que seja, possa ir ao sertão buscar gentios por nenhum modo, nem trazê-los ainda que seja por sua vontade (...) (VIEIRA, 1925, p. 426).

Sendo esta uma regulação que outrora foi requerida pelos jesuítas, observa-se que esse foi um exemplo de agraciamento feito por parte da majestade a uma das partes envolvidas nessas relações de poder do contexto em que o autor das cartas se encontra.

No decorrer do texto de Vieira, ele faz sugestões sobre o perfil que o rei deveria favorecer para escolher o súdito que viria assumir o cargo de governador da capitania, ele aconselha sobre esse quesito usando como exemplo um nome de alguém que segundo o mesmo se trata de uma boa escolha.

De André Vidal direi a V.M o que me não atrevi até agora, por me não apressar; e, porque tenho conhecido tantos homens, sei que há mister muito tempo para se conhecer um homem. Tem V.M. mui poucos nos seus reinos que sejam como André Vidal; eu o conhecia pouco mais de vista e fama: é tanto para tudo o demais como soldado: muito cristão, muito executivo, muito amigo da justiça e da razão, muito zeloso do serviço de V.M e observador das suas reais ordens, e sobretudo muito desinteressado. (VIEIRA, 1925, p. 447).

Ao falar das características de ${ }^{\mathrm{I} 2} \mathrm{André}$ Vidal, percebemos que o padre parece tentar justificar que o fato do homem citado ser tão virtuoso e preparado para tal cargo é pelo fato do mesmo ser muito cristão. A partir daí nota-se que o braço eclesiástico é importante em qualquer que seja a esfera do corpo social, mesmo que cada corpo tem uma função a cumprir, a religiosidade devia estar presente na cultura política. O fato do súdito ser compromissado com os valores pregados pela igreja o torna uma pessoa de confiança e amiga da justiça e da razão na concepção de Antônio Vieira. O súdito recomendado pelo padre Vieira fora escolhido pelo monarca. Esse ato de atender a um pedido de um súdito faz com que aquela pessoa tenha um reconhecido espaço de poder na sociedade.

\footnotetext{
${ }^{12}$ André Vidal de Negreiros, brasileiro, que se distinguira em Pernambuco na guerra com os holandeses, fora nomeado governador das duas capitanias do Maranhão e Pará em conjunto, conforme fora aconselhado Vieira na carta LXVII.
} 
$\mathrm{Na}$ maioria das cartas analisadas, nos deparamos com uma temática que tem mais a característica de relatório do serviço missionário. Esse extenso texto, como em outros anteriormente, conta sobre os empecilhos que atrapalham o progresso da missão jesuíta na região, o padre como de costume faz uma série de recomendações e conselhos ao monarca Dom João IV, onde mais uma vez fala sobre as mazelas dos colonos perante os indígenas e das formas que essa relação com eles afeta o trabalho missionário.

A governança para a glória de Deus: os conselhos cristãos para manutenção da ordem e justiça

Através dos conselhos ofertados aos monarcas portugueses - Dom João IV e Dom Afonso VI, notamos como essa personalidade sacerdotal determina as condutas da realeza durante o Antigo Regime português. Pode-se perceber que através de seu local de fala ${ }^{13}$, Vieira como representante da fé católica usa de boa articulação nas palavras e retórica sofisticada para conseguir desempenhar seu papel de conselheiro eclesiástico.

O fato da nobreza receber conselhos do clero para administração do poder é utilizado em todo o Antigo Regime - desde a queda do Império Romano até a Revolução Francesa - esse costume é apontado no livro do historiador Marcelo Tadeu dos Santos.

A ordem natural e social eram consideradas equivalentes e garantidas pela ordem divina, o que fazia com que o poder temporal tivesse a obrigação de compartilhar com o poder religioso a responsabilidade de garantir a ordenação social. Tal imbricação ancorava-se no pensamento teológico construído a partir da Idade Média. (SANTOS, 2013, p. 87).

$\mathrm{O}$ trecho anteriormente citado nos revela que quem possuía a autoridade para reger o comando sobre a administração temporal e espiritual da vida das pessoas, tinha essa autoridade oriunda da graça divina, e essa autoridade deveria corresponder mantendo a ordenação social, esse pensamento está em sintonia com o

\footnotetext{
${ }^{13}$ Neste presente trabalho, entende-se por local de fala, um termo inspirado no conceito de Relação de Força da obra que Eni Orlandi, que salienta que quanto mais destacada é a posição ou condição social do emissor do discurso, mais significante e impactante é a mensagem emitida.
} 
recomendavam os filósofos que enalteciam os valores monarquistas, como o francês Jacques Bossuet.

Existia uma distribuição de benefícios por parte dos administradores do reino. O nobre tinha que ouvir as demandas dos corpos sociais com influência na sociedade, e atendendo parte dessas solicitações eram dados espaços de poder frente á classe nobre. Percebe-se em alguns desses relatos um costume herdado na Idade Média, de que uma ordem vinda da realeza ou nobreza muitas vezes não era obedecida, mas a mesma deveria ser reconhecida.

O pensamento político de padre Vieira gira em torna de uma razão de estado católica. Seu discurso para influenciar na administração do reino está pautado em referência a identidade da Providência Divina, assim como era feito nos sermões e nos discursos proferidos por ele nos púlpitos. Esse método de salientar o comportamento das pessoas está resumido na afirmação do cientista político, Alessandro Coelho:

Eis, portanto, o "método" e caminho empregados pelo jesuíta: I) apresentar uma doença/enfermidade; 2) demonstrar a necessidade de um remédio e, assim, 3) justificadas pela obrigação no mundo temporal, atitudes e ações de todos passam a ser dever maior que se revela na identidade da Providência Divina. Portanto, parece mesmo ser isso que Vieira procura fazer, isto é, busca dar sentido e materialidade ao mundo pensado por meio de suas ações, pareceres, cartas, conselhos, ou em seus sermões, todos eles, instrumentalizados por uma oratória envolvente que combina e mantém indissociável seu discurso sempre retórico, político e teológico. (MANDUCO COELHO, 2005, p 136).

Conforme lembra este método afirmado por Alessandro Coelho, Vieira utilizava com clareza do que discorre o cientista político: apresentar uma doença e demonstrar a necessidade de um remédio, essa é a principal receita utilizada nas cartas, expor os principais problemas enfrentados pelos missionários e sugerir possíveis comportamentos para solucioná-los. Sobre a importância dos posicionamentos do religioso jesuíta e sobre essa capacidade que o mesmo tinha para compreender e ditar os variados problemas, ilustra bem Soares:

Vieira foi, sem contestação, uma das maiores figuras do século XVII; e o foi não só como escritor e como pregador que dominava; 
com invulgar talento, a arte de escrever e de falar; mas também como inteligência, capaz de compreender os grandes problemas religiosos, morais, políticos, sociais e econômicos de sua época, e como homem de ação. Daí não ser possível entender e avaliar a cultura de seu tempo, sem conhecimento de sua vida e de sua obra (quinhentas cartas e duzentos sermões). (SOARES, 2004, p io).

Nota-se também diante do corpo documental estudado, uma linguagem bem estruturada. Podemos encontrar uma riqueza literária que embasava a argumentação de personagens importantes nos registros escritos. Como exemplo disso, pode-se destacar o fragmento abaixo que é oriundo de uma carta feita por Antônio Vieira em I655 que resume significantemente uma ideia de Estado na visão do religioso, que se posiciona através de seus conselhos para o rei D. João IV, que cabe ouvir os apelos do "braço eclesiástico".

Se o braço eclesiástico ajudara ao secular, tudo se pusera facilmente em ordem e justiça; mas, como as cabeças das Religiões, têm opiniões contrárias às que Vossa Majestade. Manda praticar então as consciências como de antes, e o que não nasce destas raízes dura só em quanto dura o temor. (...). (VIEIRA, 1925, p 446).

Na citação abaixo é evidenciada a característica do rei, de querer seus súditos no caminho da salvação, anteriormente neste trabalho, menciona-se o termo braço eclesiástico, esse braço que através dos seus conselhos, deve auxiliar a cabeça da ordem social, que é o rei a manter a justiça baseada nas tradições da fé católica e a servidão da majestade para que ambos os papéis caminhem de mãos dadas na cultura política na manutenção da cultura política, pois enquanto rei fornece os benefícios que a religiosidade solicita, os religiosos levam a fé cristã para outros povos enquanto faz os novos fieis passarem a ser súditos do reino.

O rei é misericordioso, age preocupado com seus súditos, os quer no caminho da salvação e da glória, imitando a Deus e buscando a perfeição. Agraciar é fazer com que o súdito se sinta parte daquele universo sagrado, representado na terra pelo rei, universo sacralizado pelo acordo que fez de Portugal representante e guardião da fé católica. É claro que como bom pastor, o monarca tem de recorrer ao cajado para afastar os lobos. (SANTOS, 2013, p I83). 
Na última carta do Pe. Antônio Vieira para o sucessor de Dom João IV, seu filho Dom Afonso VI, são encontradas no decorrer do texto, lembretes do compromisso por parte da realeza na gestão do reino, o seu papel como mantenedor da ordem e da paz, o seu dever de defender a justiça social. No trecho final da carta percebe-se também que Vieira fala do papel do missionário que precisa ser fiel ao serviço do rei de Portugal, desde o que o mesmo siga os preceitos de Deus.

\section{Considerações Finais}

Os mecanismos que compõe as relações de poder durante o Antigo Regime estão fundados em princípios teológicos que, conforme se percebeu no decorrer da análise das epistolas feita aqui, estão presentes na argumentação bem fundamentada do religioso estudado. As posições defendidas por Vieira rementem a uma valorização da visão de um mundo hierarquizado, que tem o monarca como o ator principal em um teatro de relações políticas, mesmo em uma sociedade hierarquizada com grupos sociais distintos, existe uma colaboração entre eles, onde o personagem principal compartilha seu poder com aqueles que merecem.

Nesse artigo vimos que o plano de difusão evangélica, orquestrado por Antônio Vieira, é alicerçado a uma razão de estado católica, que ao catequizar o indígena, quer fazer dele tão bom cristão, quanto bom súdito da coroa portuguesa, fazendo do campo missionário, a difusão de um pensamento político argumentado no evangelho.

Nas cartas analisadas a realidade é representada por um conjunto de significações que são alicerçadas no pensamento religioso. Dessa forma, é possível perceber o ideário de uma sociedade que deve ser enraizada nos costumes cristãos, pois para Vieira, a vida em sociedade e a administração do reino estão mais próximas da ordem e da justiça, se a monarquia aceitar os conselhos da figura religiosa para tomada de decisões na condução do estado.

Nessa perspectiva, vemos o religioso Vieira como uma figura que mesmo doutrinatária, tem uma bandeira a defender e um ideal de sociedade bem arquitetado em suas alegorias linguísticas. Ao defender esses ideais, sua linha argumentativa traça um perfil que o monarca deve reger, ser uma personalidade compromissada 
com a expansão da fé católica, que deve governar de acordo com a providência divina, onde integrar o índio na fé cristã é fazer com ele este unido a esse universo onde o reino português visaria a redenção e salvação de seus súditos.

A pesquisa demonstra que o papel da monarquia em relação à religiosidade, se refere a uma paz construída nos moldes do conceito de ordem coorporativa, contida na característica de que, cada corpo social tem uma função destinada, onde o a monarquia é a cabeça do reino, que com o auxílio do braço eclesiástico, rege, as devidas providências para a manutenção da ordem social entre os súditos e fiéis.

Em uma batalha contra o pecado e o mal, Vieira faz do epistolário sua arma para salientar o monarca português de seu compromisso com a cristandade, as cartas fazem parte de um engenhoso projeto político e teológico, onde o religioso jesuíta cobra posições favoráveis em relação a aquilo que ele acredita ser o melhor de acordo com seu pensamento político.

As cartas podem ser consideradas como um arsenal intelectual que demonstram o pensamento político de Vieira, que bem fundamentado se volta para a edificação de um forte estado português, onde a realização plena das virtudes de harmonia e paz, pregadas pelo cristianismo não dependem apenas da ação direta da Divina Providência, mas sim, de um instrumento utilizado por ela, um estado administrado por “mãos de homens," mas voltado para a maior glória de Deus.

\section{Referências}

ALVES, Deivide Rodrigues. “O pregador e a razão de Estado em António Vieira: o sermão e a formação pregacional como bases para a construção do Quinto Império Português”, 2015. 12If. Dissertação (Mestrado em Letras) - Universidade Estadual do Sudoeste da Bahia, Vitória da Conquista, 2015.

AZEVEDO, J. L. História de Antônio Vieira, 2 vol. Lisboa: Livraria Clássica Editora, I93I.

BASCHET, J. A Civilização Feudal: do ano mil a colonização da América. São Paulo: Ed. Globo, 2006. 
BERNSTEIN, S. "A Cultura Política” in: RIOUX, J. P. SIRINELli, J. F. Para uma História Cultural. Lisboa: Estampa, 1998. p. 351-363.

COELHO, M. F. “Um Olhar Medieval sobre o Brasil Colônia”, in: Revista Múltipla, Brasília 7(I2): I13 - 130, julho - 2002.

FALCON, Francisco. História e poder. CARDOSO, Ciro Flamarion. VAINFAS, Ronaldo.(Orgs.) Dominios da História:. Ensaios de Teoria e Metodologia. Rio de Janeiro: Campus, p. 6r-89, 1997.

GINZBURG, Carlo. Sinais: raízes de um paradigma indiciário. Mitos, emblemas, sinais, p. I43-179, 1989.

GONÇALVES, Eugênio Mattioli. Princípios da Razão de Estado em O Príncipe, de Nicolau Maquiavel. Filogenese. Marília, v. 3, n. I, p. 7-14, 2010.

MANDUCO COELHO, Alessandro Manduco. "O empenho de Antonio Vieira". Lua Nova, n. 59, p. 115-135, 2003.

MANDUCO COELHO, Alessandro. "Retórica e razão de Estado católica: o pensamento político do padre Antonio Vieira em favor da monarquia lusa”. In: Prisma Jurídico, núm. 4, Universidade Nove de Julho, São Paulo, p. 125-139, 2005.

ORLANDI, Eni P. Análise de Discurso: princípios e procedimentos. $5^{\mathrm{a}}$ ed. Campinas, SP: Pontes, 2003.

REMOND, René in LINHARES, Maria Y. Leite. Por quê a História Política?. 1993, p. 8.

RÉMOND, René; ROCHA, Dora. Por uma história política. Editora FGV, 2003.

SANTOS, M. T. A majestade do monarca: justiça e graça nos sermões de Antônio Vieira (1653-1662). - São Paulo: Anablume, 2013. p. 87-183. 
SOARES, Samuel. Introdução In: Sermões: problemas sociais e políticos do Brasil. São Paulo: Cultrix, 2004. p. 6-I5.

VIEIRA, "Cartas do Padre Antônio Vieira coordenadas por J. Lúcio Azevedo". Coimbra: Ed. da Universidade. 1925.

XAVIER, A.B.; HESPANHA, A.M.” A representação da sociedade e do poder” In: MATtOSO, J. (dir.) História de Portugal. Lisboa: Editorial Estampa 